\title{
The Justice and Development Party Government and the Military in Turkey
}

\section{Metin Heper}

To cite this article: Metin Heper (2005) The Justice and Development Party Government and the Military in Turkey, Turkish Studies, 6:2, 215-231, DOI: 10.1080/14683840500119544

To link to this article: https://doi.org/10.1080/14683840500119544

曲 Published online: 25 Jan 2007.

Submit your article to this journal ๘

Џll Article views: 1082

Citing articles: 16 View citing articles 5 


\title{
The Justice and Development Party Government and the Military in Turkey
}

\author{
METIN HEPER \\ Department of Political Science, Bilkent University, Turkey
}

\begin{abstract}
Civil-military relations in Turkey have always been problematic. On several occasions the military has intervened in politics. With the coming to power of the Justice and Development Party (AKP) in November 2002, those relations could have taken a new twist, for the military in Turkey has always been a robust guardian of secularism and there has been a suspicion on the part of the military and other secularist groups in that country that the AKP was engaged in dissimulation (takiyye), and that it would sooner or later try to bring back in Turkey a state based on Islam. The present essay takes up this issue and in particular indicates instances of hostile relations between the military and the AKP turning into cooperative, if not friendly, ones.
\end{abstract}

When it comes to civil-military relations in liberal democracies, civilian government has the last word. On the other hand, the military has autonomy concerning its internal functioning and most matters of operations, and is consulted by the civilian government on issues related to security. ${ }^{1}$ In Turkey, for a long time, there have been two notable behavioral patterns on the part of civilian governments in their relations with the military: they have either tried to relegate the military to the sidelines or they have granted it too much autonomy. ${ }^{2}$ Furthermore, on the whole, civilian governments have not been successful in solving critical problems faced by the country. Consequently, the military often came to have low confidence in the competence of civilian governments. In the process, a "fragile concordance" was established between civilian governments and the military, ${ }^{3}$ whereby politicians and officers turned into hostile adversaries, instead of being friendly adversaries.

More specifically, when the civilian governments had the upper hand they tried to divest the military of all authority, as one observed in the 1950s. This led to a backlash from the military; in 1960, the latter removed the Democratic Party (Demokrat Parti, DP) government from power. In the following decades, on the whole, the civilian governments granted the military too great an autonomy and, at times, even a free hand for formulating policies in respect to the internal as well as the external security of the country. During the 1980s, Turgut Özal as prime minister attempted to reverse the latter trend, and was fairly successful in achieving this goal, even

Correspondence Address: Metin Heper, Department of Political Science, Bilkent University, Bilkent 06800, Ankara, Turkey. Email: heper@bilkent.edu.tr 
challenging the military's candidate for chief of staff. ${ }^{4}$ At the same time, Özal pursued a successful economic policy. ${ }^{5}$ In the late 1980 s, the military, to a great extent, stayed out of politics. At the time, however, civil-military relations were rather tense because Özal was inclined to a one-man show on matters of foreign policy and defense. ${ }^{6}$

It was only during the Bülent Ecevit, Devlet Bahçeli and Mesut Yılmaz coalition government of 1999-2002 that the government and the military again became friendly adversaries. That government acted in a responsible manner, adopted successful structural reforms in the economy, and initiated the still-continuing liberalizing and democratizing wave with a view to rendering Turkey a full member of the European Union (EU). The government in question also acted in a courteous but firm manner toward the military. In turn, the military, of its own volition, mostly tended not to interfere in politics. ${ }^{7}$

Against all expectations, the relationship between the military and the Justice and Development Party (Adalet ve Kalkınma Partisi, AKP) government has been essentially another example of concordance between politicians and officers in Turkey despite the still-lingering strong doubts on the part of the bulk of the secular establishment concerning the "ulterior motives" of the (pious) AKP leaders. Contributing factors here seem to be the increased reluctance on the part of the military to intervene in politics since the 1980s, on the one hand, and the gradual adoption by the religiously oriented parties of a system-oriented, that is, a pro-democratic, stance from that period onwards. Still more decisive have been the particular roles played by Chief of Staff General Hilmi Özkök and the AKP leader and (since March 2003) Prime Minister Recep Tayyip Erdoğan. ${ }^{8}$ This essay first takes up the attitudes and praxis of the military towards the AKP government. It then examines the AKP government's strategy vis-à-vis the military. The essay ends with some concluding observations.

\section{The Military}

The extent of the Turkish military's involvement in politics has fluctuated from the establishment of the Republic in 1923 to the present. The high points were, of course, the military interventions of 1960-61, 1971-73, and 1980-83, as well as the 1997 political crisis during which the military played a leading role in ousting from power the coalition government led by Necmettin Erbakan of the religiously oriented Welfare Party (Refah Partisi, RP). On the other hand, in order to prevent one coup following the another in the post-1961 military intervention period a number of steps were taken: (1) the role of the military in political life was both legalized and institutionalized; (2) the generals preempted the colonels and other lower-ranking officers in taking various initiatives; (3) the aims of the interventions were narrowed down in their scope; and (4) indirect interventions replaced direct interventions. ${ }^{9}$ These developments were basically the consequence of the military's efforts not to repeat its past mistakes. From around 1999 onwards, various governments' attempts to render Turkish democracy to conform to the EU's acquis 
communitaire so as to enable that country to become a full member of the EU have provided a new impetus for the civil-military relations in Turkey to begin to evolve towards the pattern one comes across in liberal democracies.

It was under such circumstances that General Özkök became chief of general staff. This change of guard at the highest post in the military has played an important role in maintaining civil-military relations as those between friendly adversaries. For Özkök took Atatürkism-the guiding light of the Turkish military-as a worldview open to change, and not as an ideology, i.e., a closed system of thought. This was demonstrated, for instance, through his treatment of journalists, to whom Özkök voiced his thoughts rather than laid down the law on how he should act under certain circumstances. ${ }^{10}$ For the most part he was careful to avoid repeating the worn-out clichés; instead, he made a genuine effort to come up with a policy best fitting the changing circumstances. It is true that he was "proud to declare" that the Turkish Armed Forces (Türk Silahlı Kuvvetleri, TSK) played a pioneering role in the modernization of Turkey and that Turkey has been a member of NATO for several decades; yet, unlike some, both in the military ranks and society at large, Özkök did not perceive modernization as merely a form — an outward appearancebut first and foremost as a thinking pattern for "evaluating different options and selecting the best one." 11

According to Özkök, the TSK should have a new vision. Officers should not be satisfied only with emulating the past. There was a need for widening the intellectual horizons of officers. Along the same lines, Özkök even thought that there was a need for reinterpreting Atatürkism. ${ }^{12}$ He has pointed out that "one cannot be an Atatürkist only by carrying on one's lapel an Atatürk badge. One has to be able to look at the same direction as Atatürk did, and have the same foresight that Atatürk had." ${ }^{13}$ Most strikingly, it has been reported that Özkök has questioned the wisdom of military interventions in politics and has praised a more democratic solution:

The military intervened on May 27 [1960], March 12 [1971], and September 12 [1980]. Were these interventions successful? No! If they had been successful, politicians who had been banned from active politics could not have been able to return to politics. Those who were banned from politics later became even prime ministers and/or the president of the republic. This shows that military interventions are not panacea. From now on we should have greater trust in the people's judgment. ${ }^{14}$

Özkök had plans to revise the curriculum of the military schools in order to bring up a new generation of officers who would also have trust in the people's judgment. ${ }^{15}$ In a parallel manner, Özkök has stated that patriotism in Turkey is not a monopoly of the military. ${ }^{16}$

In addition to the growing confidence in the judgment of the people, Özkök thought that religion might play a role at the individual, community and/or state levels; that is, pious people may pursue secular politics. Thus, he came to have respect for people's religious beliefs and preferences "as long as they were not 
carried to the public realm as a symbol of political Islam." ${ }^{17}$ Consequently, when the AKP was victorious in the November 2002 elections, Özkök responded to a question put to him by a journalist as follows: "We have had elections in accordance with democratic rules ... The results reflect our people's preferences, for which I have respect." ${ }^{18} \mathrm{He}$ then sent his congratulations to Recep Tayyip Erdoğan, who at the time had still not been elected to Parliament. A couple of weeks later, on his official visit to the United States, Özkök told the Administration officials in Washington, DC that the elections in Turkey had taken place in accordance with the relevant rules and regulations, and were not a cause for worry.

This particular stance on the part of the Chief of General Staff vis-à-vis the AKP victory was also a reflection of the military's respect for constitutionalism, one earlier manifestation of which was the military's post-1961 penchant for the legalization as well as institutionalization of the role of the military in Turkish politics. The military's respect for constitutionalism continued during the AKP government, too. In January 2003 Özkök called on all to act in accordance with the decisions of the Constitutional Court and the Council of State concerning the controversial headscarf issue of whether or not female students should be allowed to attend classes at universities with their hair covered. ${ }^{19}$ Similarly, in March 2003, when the military was criticized for not openly supporting the passage in Parliament of the government's resolution to allow the Americans to open a second front in the north in the then impending war in Iraq, Özkök pointed out that if the military at the time had wished to make a recommendation on the issue it could not make that recommendation to Parliament because, according to the Constitution, the military can make such recommendations only to the government. In the summer of 2003, in his turn, then Vice-Chief of Staff General Yaşar Büyükanıt, who at the time was expected to become Turkey's next chief of staff in 2006, made it known that during the deliberations on the reform packages that the government had prepared to render Turkish democracy compatible with the EU acquis communitaire, the top command had conveyed their views to the government; the government adopted only some of those recommendations; and upon Parliament's enactment of the reform packages into law it had become the duty of the military to comply with the new legislation. At the time, Büyükanıt also pointed out that nobody should make a state versus government distinction, i.e., state elites, comprising officers, who focus on the general interest as against political elites who only promote sectional interests, for it was Parliament which has the last word on whether or not to send troops to Iraq. ${ }^{20}$

Özkök's basic respect for the dictates of liberal democracy led him to do his best in keeping his distance from day-to-day politics. When he had been commander of the landed forces, he had hardly made public statements to journalists. On the eve of the November 2002 national elections, when he had been asked by journalists which political party he was going to cast his vote for, Özkök replied by saying, "You do not ask soldiers such questions. In any case, I prefer not to make comments on politics. We soldiers shall go and vote in our capacity as citizens, not as soldiers." ${ }^{21}$ Later, too, to the extent possible, Özkök remained loyal to the same principle; in his view, every public institution should attend to its own business. Thus, on the question of 
whether a second front should be opened in the then impending Iraq war, he first carefully distinguished between the military and political aspects of the issue and then expressed his views on the former, but not on the latter. ${ }^{22}$

All along, Özkök and his co-commanders have sought to develop a modus vivendi with the AKP government. When in their opinion the AKP came up with a reasonable counter-argument on a controversial issue, the commanders waived their own request made to the AKP government. Following the November 3 elections, Özkök had asked Erdoğan who his candidate was for prime minister. When Erdoğan responded by pointing out that it would be proper for the president to disclose that name, and not he himself, Özkök deferred to his judgment. ${ }^{23}$

As a result of the emerging harmonious relations between the military and the government, on several occasions Özkök made efforts to persuade the AKP leaders rather than simply to try to impose the will of the military upon them. When the Speaker of Parliament, Bülent Arınç, had suggested that as part of the general privatization policy the apartment blocks where officers lived should also be privatized, Özkök was able to dissuade him by explaining that in cases of sudden emergency the housing pattern in question made it easy for the officers corps to assemble quickly, in addition to it also providing for the personal safety of officers. Similarly, when the AKP Foreign Minister Abdullah Gül had registered his reservations to the expulsion from the military of some commissioned and non-commissioned officers by the High Military Council (Yüksek Askeri Şura, YAŞ) on the grounds that "they had subscribed to political Islam," Özkök patiently explained the reasons behind the expulsions, including the cases of the non-commissioned officers giving orders to commissioned officers because the former occupied a higher rank than the latter in a religious order in which both were members. To give another example, when a certain ministry and the military held contradictory opinions on matters of policy, the Office of Chief of Staff tried to solve the difference of opinion by allowing the ministry some time to retract its controversial statement, and if the ministry did not set the record straight within a reasonable period of time only then did the military set it right themselves, though doing it as diplomatically as possible. At times, the Office of Chief of Staff even changed a decision it had made upon the request of the Foreign Ministry. On one occasion, the military had made plans to invite the Iranian chief of staff to Turkey. They dropped the plan when Foreign Minister Gül told Turkish Chief of General Staff Özkök that the purpose of the visit could be misconstrued by the United States. The military's diligence to maintain a modus vivendi with the government led the Chief of General Staff at some point to suggest a meeting with the Prime Minister, who was being hounded by the media for some juicy anti-government remarks, to iron out between them any serious difference of opinion on significant matters instead of being engaged in a public debate.

Not unexpectedly, what made the military move away occasionally from this accommodating stance towards the AKP government has been "political Islam," or the presumed efforts on the part of the government to bring back a state based on Islam. Only about two-and-a-half months after the AKP government had come to power, Özkök tersely stated: “The February 28th was the consequence of certain 
developments in Turkey. The effect would not be different if the causes continue to exist." ${ }^{24}$ In May 2004, when the government tried to enable the graduates of the Prayer Leader and Preacher Schools (Imam-Hatip Okulları, IHOs) to compete on an equal footing with the graduates of other high schools for entrance to higher institutions of learning, the military seemed to have come to the conclusion that the "cause" had not disappeared. The Office of Chief of General Staff, apparently reflecting the military's concern with the possibility of the "reactionary graduates of the İHO eventually capturing the state from within in their quest for a state based on Islam," or striving to appease such concerns in the ranks and/or among some generals, declared that the proposed amendment violated the secular premises of the Republic. $^{25}$

On the other hand, from the late 1990s onwards, the military went along with several changes in civil-military relations for the sake of Turkey's accession to the EU. In 1999 the State Security Courts were entirely civilianized. In 2001 the number of civilian members of the National Security Council (Milli Güvenlik Kurulu, MGK) was increased and the recommendations made by the MGK to the government were rendered less binding for the Council of Ministers. In 2003 the Turkish Armed Forces were brought under the complete judicial control of the Court of Accounts. That same year it was made possible to appoint a civilian as the Secretary-General of the MGK, and in August 2004 Ambassador Yiğit Alpoğan was appointed to the post. ${ }^{26}$ Given the fact that the military has always preferred to justify its interventions in politics with reference to duties set for it by the Constitution and other legislation it must not have been easy for the military to consent to those reforms, but it did.

Furthermore, the military did its best to dispel concern in Turkey and abroad that the military was dictating its preferences to the government. Thus, when the military felt the need to express its dissatisfaction with a "pro-Islam" discourse and/or praxis on the part of the government, they did it in an indirect manner. Thus, shortly after the AKP came to power, when the wife of Bülent Arınç, wearing a turban, accompanied her husband to the airport to see the President and his wife off on an official trip abroad, the members of the top command paid the traditional courtesy visit to Arınç, but hinted their disapproval by refusing to have the refreshments offered to them and abruptly leaving. In contrast, virtually all the high-ranked generals attended in their full uniforms such events as the funeral of a staunchly secular faculty member, the ceremony commemorating the 100th anniversary of the abrogation of the Caliphate and the Ministry of the sha'ria, and the introduction of the "unified," i.e., solely secular, education. Also, in the wake of the İHO controversy, on the Youth and Sports Day ceremonies at a stadium in Ankara, the members of the high command refrained from applauding the speech of a student from a Prayer Leader and Preacher School while everybody else in the VIP stand did.

\section{The AKP Government}

Prime Minister Recep Tayyip Erdoğan's hold over his party and government has always been significant, and it became more so as time went by. Erdoğan valued 
debate and exchange of opinions; at the same time he expected others to respect the final decision he himself made. Erdoğan led the party and the government in cooperation with his close colleague Abdullah Gül, foreign minister and vicepremier. Thus, given the apprehension of the secular establishment, including the military, about the "ulterior motives" of the AKP government, that is, whether that government was trying to bring back, at an opportune moment, a state based on Islam, the very future of the government depended upon how Erdoğan and his few close colleagues conducted themselves in politics. On the whole, Erdoğan and his colleagues passed the military's litmus test of acting rationally and responsibly in politics as well as keeping their distance from Islam.

Early in his career in the religiously oriented political parties led by Necmettin Erbakan, Erdoğan had seemed for a while to share some of the views that his then mentor Erbakan had advocated. Yet, even during his years in the Welfare Party he had started to put a distance between himself and Erbakan. For instance, it was Erdoğan, not Erbakan, who had made it possible for women to participate more actively in politics in the ranks of the religiously oriented parties. In any case, having attended the İskenderpaşa congregation in his youth, Erdoğan subscribed to Sufi Islam, and as such he believed in higher cihad, or efforts to upgrade one's own morality and that of others, and not in lower cihad, of forcefully converting others to Islam. While metropolitan mayor of Istanbul, Erdoğan had banned alcoholic drinks only in the restaurants run by the municipality, but not even in those restaurants rented out by the municipality. During those years Erdoğan turned out to be the first mayor of Istanbul to set aside funds for the renovation of churches and synagogues in that city. As a Sufi, Erdoğan did not favor using Islam for political gain. ${ }^{27}$

Having observed the fate of the religiously oriented parties under Erbakan, Erdoğan, Gül and a few other close colleagues of his parted ways with the former's orthodoxy and his entourage, and formed their own party, the AKP, which defined itself as a conservative-democratic political party. ${ }^{28}$ Erdoğan favored a secular state, because, in his view, if the state were not separated from religion "the mistakes committed by the state would have been attributed to religion." ${ }^{29}$ In January 2004, at the Jiddah Economic Forum, Erdoğan and Gül lectured before their Muslim colleagues on the necessity of separating religion from politics. They pointed out that Turkey has been able to live under a secular-democratic state while keeping its indigenous moral values alive. The AKP government also kept the headscarf issue on the backburner. Instead, it worked hard to complete the harmonization of Turkish legislation with the acquis communitaire so that Turkey would be able to obtain a date from the EU for the start of accession negotiations. In June 2004 the EU decided to discontinue the monitoring of the democratization process in Turkey, having arrived at the conclusion that Turkey came close to conforming to the EU standards concerning democracy, the rule of law and human rights. In October 2004 Günther Verheugen, the EU's enlargement commissioner, categorically stated that Turkey fulfilled all the requirements for obtaining a date from the EU for the start of the accession negotiations. Two months later the AKP did obtain a date. 
The AKP government has also been quite successful concerning the economy. It continued to pursue the austerity program formulated by the International Monetary Fund (IMF) and put into effect by the earlier coalition government under the stewardship of economist Kemal Derviş from the Republican People's Party (Cumhuriyet Halk Partisi, CHP), though to some extent bringing to it a human face. The government also stayed away from populist policies. In May 2004 the GeneralDirector of Euro-Asian Onduline Construction Materials Holding Company reported that their sales had not gone up (for illegal construction activity in squatter areas) for the first time on the eve of a local election in Turkey. ${ }^{30}$ When people asked for jobs, Erdoğan told them that they should find jobs independently and work hard. In July 2004 the government initiated a change in the Penal Law that brought stiff penalties for illegal construction in the squatter areas. It must be as a consequence of such policies that in February 2004, for the first time in 28 years, inflation was below ten percent (9.1 percent). That same month, Erol Sabanc1, the CEO of Akbank of the Sabanc1 Group, pointed out that their worst fears about the AKP government have not been borne out; they have been able to develop dialogue with the government, and the government has successfully grappled with economic problems. ${ }^{31}$ In March 2004 a public opinion survey conducted by the Social and Economic Foundation of Turkey (TÜSES) found that, according to 64 percent of the respondents, the economic situation in Turkey had improved compared to 12 months previously; according to 20 percent, it had stayed the same; and according to only 16 percent had it become worse. ${ }^{32}$ It is true that, as of October 2004, the trickle-down effect of these developments had not yet materialized to a significant degree; however, in all probability the government's efforts to bring about the said improvements in the economy were not lost on the military.

All along, the AKP government pursued a careful and balanced policy towards the military. First, the government tended to avoid measures that the military would have strongly opposed. In December 2002 Minister of Defense Vecdi Gönül, in line with the military's view on the issue, let it be known that the Office of Chief of General Staff would continue to report to the prime minister's office, and not to the ministry of defense, the latter of which is the case in the majority of the EU countries. ${ }^{33}$ In April 2004 Prime Minister Recep Tayyip Erdoğan pointed out that it was not in his government's agenda to amend the Internal Service Act of the military, ${ }^{34}$ which, in its present form, enables the military to enhance its role and defend the country against internal as well as external threats, if necessary by resorting to force. In July 2004 Minister of Justice Cemil Çiçek blocked the insertion of a provision to the Penal Law that would have penalized those who had prevented the female students with a headscarf from entering university grounds. Thus, Çiçek chose not to confront the military, which does not want to see female students with headscarves on university campuses.

Second, the AKP government has refrained from criticizing the military openly on those issues about which the military is quite sensitive: In January 2003 Erdoğan kept quiet when Özkök complained about the reservations that Prime Minister Abdullah Gül had registered concerning the dismissal by the High Military Council 
of a number of commissioned and non-commissioned officers from the military on the grounds that they were involved in political Islam. ${ }^{35}$ Instead, when a number of officers died as a result of a military plane crash, Erdoğan sent his condolences to Özkök.

Third, at times Erdoğan commended the military while criticizing the AKP parliamentarians. In July 2003, during the deliberations of an AKP parliamentary group meeting on whether amnesty should be provided to non-violent members of terrorist organizations, Erdoğan warned the AKP parliamentarians by saying, "Your judgment on this issue cannot match that of the Office of Chief of General Staff. The latter office, along with the Foreign Ministry, supports such a measure."36

In consequence to the above, the AKP government has paid attention to the military's views concerning those matters on which the military had expertise. On the question of whether or not Turkey should send troops to Iraq, Foreign Minister Gül made the following comments: "The military's view on this issue is important. However, that fact would not oblige us to devolve [our] whole authority to the military. The final authority to make such political decisions rests with the government. Yet, it would be inappropriate not to find out the military's thinking on this matter." 37 Finally, just as the military strove to develop a modus vivendi with the government, the AKP government, too, tried to achieve the same goal. Both Gül and Erdoğan, as prime ministers, suggested that the government and the military should get together as often as necessary and go over the issues on which the military is sensitive. $^{38}$

On the other hand, on some occasions, while commending the military, in between the lines, the AKP government has also sent messages to that institution that the civilian government was in a superordinate position to the military. Erdoğan, Gül, Minister of Defense Vecdi Diker and Minister of Justice Cemil Çiçek took turns in this delicate task.

Erdoğan: When Turkey started to modernize, the military began to play a role in the polity, which was in line with the relevant provisions of the [1924] Constitution. The military intervened in politics only when there was a political vacuum; the military played a somewhat expanded role because the political will was weak. Today, we have a government that has the support of 66 percent of the electorate. Thus the military would no longer be obliged to intervene in politics. We came across such a situation during the Özal years, too. ${ }^{39}$

Gül: "The military is sharing its views with the government. The government is discussing the issues and making its own decisions." 40

Gönül: That the military has certain sensitivities should not come as [a] surprise. On the other hand, there is no reason to expect those sensitivities to cause problems for the government. In line with our state tradition, relations between the government and the military will continue to be harmonious. The military has utmost respect for the laws of our country. ${ }^{41}$ 
Çiçek: An MGK meeting is not an arena where gladiators fight with each other; it is not a service to the country to report each and every meeting of the MGK as a clash between politicians and officers. The general impression is that in the MGK meetings politicians give an account of their policies and deeds to officers for the latter's approval. That is not what happens. The Constitution makes clear who is responsible to whom. As a minister, I am politically accountable to Parliament and, if I commit a crime punishable by law, as a parliamentarian I would be accountable to the judiciary. I am not accountable to the MGK in any of my capacities. The MGK is a constitutional platform, where everybody expresses his opinions. Not unexpectedly, there is not unanimity on each and every issue. However, in the last analysis, the decisions made in the Council are the product of the collective wisdom of the members of that Council. ${ }^{42}$

At times, the messages sent to the military were blunter. When Özkök held a media conference and pointed out that not only some generals but all members of the military were troubled by some policies of the government, Gül made the following comments:

In a democratic country everybody can express his/her opinions. The members of the TSK can [also] air their views since they too are citizens of this country. However, if the latter wish to do so as members of the TSK then they are obliged to do it in its proper venue [i.e., the MGK]. Whenever the views of the military are carried to newspaper headlines everybody begins to think that the country is facing another political crisis. ${ }^{43}$

Similarly, when the Secretary-General of the MGK, General Tuncer Kılınç, publicly expressed his dissatisfaction with some provisions in the reform packages, ViceChairman of the AKP, Dengir Mir Mehmet Firat, observed that "the reform packages may be discussed in the MGK meetings and the Council may make recommendations to the government. However, the Secretary-General of the MGK has no right to criticize those reform packages on his own right."44

On some occasions, Erdoğan even made suggestions concerning the internal functioning of the military. In reference to the more or less periodic dismissal of commissioned and non-commissioned officers from the military by the Military High Council (YAŞ), mentioned above, he ventured the idea that it may be more appropriate if the dismissals were made by the force commanders rather than the YAŞ, so that the latter council could better focus its attention on more general issues. Erdoğan also came up with the idea that since the TSK was a rather special type of institution, one may think of utilizing its personnel on a contract basis to facilitate the discharge process of personnel, if and when the need arises. ${ }^{45}$ Furthermore, when the military criticized the government, sometimes Erdoğan countered that criticism with his own criticism of the military. It has been reported that in the May 2003 meeting of the MGK, commanders had expressed their dissatisfaction 
with "the AKP government's packing the civil bureaucracy with their own supporters," and that in response Erdoğan had pointed out that the military had sometimes been acting in the same manner-that General Aytaç Yalman was appointed as the commander of the army when in fact General Edip Başer should have been brought to that post. ${ }^{46}$

\section{The Prayer Leader and Preacher School Controversy}

While the attitudes and values as well as the praxis of the military and the AKP government outlined above had tended to turn the relations between those two institutions into one of friendly adversaries, as noted, in May 2004 a mini-crisis developed around the issue of whether or not the graduates of the prayer leader and preacher schools, IHO, should have the same opportunity as that of graduates of other secondary high schools in competing for places in the higher institutions of learning. Over the years, an increasing percentage of the İHO graduates chose not to become prayer leaders and preachers; instead, they wanted to continue their higher education, and to do so not only in higher institutions of theology but in other higher institutions of learning, too. Among their numbers were female students attending the IHOs, who could not become prayer leaders or preachers, as well as a sizeable number of students who came from religiously oriented families who wished their children to receive a "sound education" in their religion on top of education in secular subjects. In order to prevent the graduates of the IHO schools from attending the secular higher institutions of learning, they were obliged to achieve higher scores than the graduates of the other schools in order to be admitted.

Given these developments, on the eve of the March 2004 local elections the AKP promised its constituents to put an end to the said "discrimination" against the graduates of the IHOs. In May 2004 the government prepared a draft law that equalized the chances of the graduates of the İHOs and those of other schools in the nationwide-held entrance examinations for university.

This initiative on the part of the AKP government was met with stiff opposition by the military as well as by the bulk of the secular establishment. Özkök observed:

The proposed amendment is against the provisions and the very spirit of the relevant Act. The latter stipulates that the graduates of the Prayer Leader and Preacher Schools should take up jobs only in religious services. Those, for whom the very premises upon which the Republic has been built are precious, cannot be expected to support the amendment in question. ${ }^{47}$

In the same statement, Özkök added that, in recent years, the military had sound reasons to oppose some changes in the Constitution and other relevant legislation, but that it had not done so because it would have had adverse implications on Turkey's efforts to become a full member of the EU. ${ }^{48}$ Özkök seemed to imply that, in contrast to the earlier amendments, the proposed amendment was something they 
could not live with. The military, alongside the bulk of the secular establishment, thought the amendment in question aimed at facilitating the penetration of the cadres sympathetic to political Islam to the civil bureaucratic posts, and thus eventually bringing back a state based on Islam.

Erdoğan tried to dispel such doubts by saying, "We do not have ulterior motives. We are trying to deal with a specific problem the country faces and we do not have the luxury of giving short shrift to popular demands." ${ }^{49}$ Hüseyin Çelik, the Minister of Education, elaborated on the "problem" and also suggested alternative solutions: "The students in Prayer Leader and Preacher Schools constitute only 1.5 percent of all the student body in the secondary school system in Turkey [and, therefore, they cannot be a threat to the secular-democratic state even if they all turned out to be sympathetic to political Islam]. ${ }^{, 50}$ A few days later, Çelik also pointed out that "students are unwilling to attend vocational schools [like the IHO], because presently the graduates of those schools have little chance of being admitted to universities." Mehmet Görmez, Vice-President of the Directorate of Religious Affairs, which is affiliated to the prime minister's office and which appoints prayer leaders and preachers to mosques around the country and monitors their activities so that they do not divert from "enlightened Islam," came up with additional arguments in favor of the proposed amendment:

The Prayer Leader and Preacher Schools are not religious schools engaged in the indoctrination of students. They are vocational schools. The students studying in these schools subscribe to different views not unlike the people at large. People have to familiarize themselves with the culture of their country. Does not religion [i.e., Islam] constitute an important dimension of the culture of the people in this country?

In response to these arguments, the then First Army Commander General Büyükanit, who, as noted, was at the time expected to become Turkey's next chief of staff, made the following observation:

In my opinion the Office of Chief of General Staff came up with a serious evaluation of the draft law [concerning the İHO graduates]. I think the government should pay close attention to what the Office of Chief of General Staff pointed out and act accordingly. Let me underline the fact that I am not trying to force the government to act one way or another. What I am suggesting is that the government should read carefully the message conveyed by the Office of Chief of General Staff.

Nevertheless, the government decided to go ahead and, since it commanded the majority of seats in Parliament, had the bill enacted into law. The President of the Republic, Ahmet Necdet Sezer, vetoed the law. According to the Constitution, if the government had chosen to have the Parliament again enact it into law intact, the President would have been obliged to sign it. Instead, the government preferred to shelve the issue. 


\section{Concluding Observations}

Despite expectations to the contrary, the AKP government and the military have managed to develop a working relationship. Their relationship came closer to the liberal model of civil-military relations than ever before. The military grants that the government has the last word. One reason here is that it favors democracy, provided that the civilian governments act in a responsible manner, make genuine efforts to grapple successfully with the problems the country faces, and most important of all, stay away from political Islam (as well as ethnic separatism). It may be argued that, so far, the AKP government has conducted itself in that particular manner. Another much more significant reason, which is a rather recent phenomenon, is that the military, or at least the present high command, came to the conclusion that an expanded role for the military, let alone military interventions of one type or another, are not panacea for the ills of democracy. At least the present high command is of the opinion that they should start having more faith in the judgment of the people, and therefore, if necessary, Atatürkism too should be reinterpreted in a more liberal direction.

Yet, the view that perhaps Turkey needs a more representative government and that perhaps the military should internalize a somewhat different philosophy does not seem to be shared by all officers, including some top generals. Will this state of affairs create difficulties for the otherwise deepening Turkish democracy in the foreseeable future? Probably it will not. This is because the high command seems to have made plans so that the next two chiefs of staff, General Yaşar Büyükanıt, Commander of Landed Forces, and General İlker Başbuğ, Vice Chief of Staff, both share Özkök's views on civil-military relations. In any case, even if some generals sometimes register their opposition to the high command's approach to civilmilitary relations, once a decision is made by the high command, the former always comply with that decision, for hierarchy continues to be a basic norm in the Turkish military. In any case, differences of opinion at the higher ranks are never about the basic worldview subscribed to by the military; they arise only about the manner in which that worldview is translated into specific strategies of action.

The intermediate goal and a more definitive step for the institutionalization in the military of the views of the present top command is, of course, that of developing a new socialization process in the ranks. As noted, Özkök has plans to materialize a transformation along those lines. If indeed in the years to come the top command will be in the hands of the generals sympathetic to Özkök's views there is reason to expect such a change in the said socialization process so that the present problem of the military from time to time intervening in politics in varying degrees would gradually become a non-issue.

It has been noted above that during the AKP government, civil-military relations in Turkey moved closer to the liberal-democratic model than ever before, implying that it has yet to adopt that model fully. After all, although the military grants that civilians will make the final decisions and that the military does not have the monopoly over patriotism, they still think that on some such critical issues as political Islam 
and ethnic separatism they have a better grasp of those problems than do civilians. They thus expect the civilian governments to act as they are told, although they give the impression that if the civilian governments do not pay attention to what they propose they will not force them to do so.

It is patent that the military would stop thinking that they are the best experts concerning certain issues if the civilian governments equip themselves with civilian advisors in whose expertise on military matters the military would have sufficient trust. Would it be reasonable to expect such a transformation taking place in the near future so that the military factor in Turkey would not stand in the way of Turkey becoming a full member of the EU? There are reasons to be optimistic in this regard. One obvious reason is the Western, if not necessarily European, vocation of the military. For more than two centuries the military has not only been the object but also the subject of modernization along Western lines. Secondly, the military must be aware of the fact that Turkey's accession to the EU will help improve the Turkish economy, which in turn will, among other things, help build a more robust military capability. Thirdly, the military, or at least the top command, analyzes the past and present carefully and takes lessons from them. For instance, from the 1980s onward, the military has not equated religion with superstition. For the military, the ideal Turkish citizen is not necessarily a non-practicing Muslim. The military is not against Islam as a source of morality. The military makes the crucial distinction between Islam at the level of the individual and Islam at the level of the state. Consequently, as far as the military is concerned, it is plausible to be pious and at the same time to be able to conduct secular politics and conduct them quite well. This, alongside their adherence to democracy, and thus to constitutionalism, must be one of the reasons why following the November 2002 elections they have decided to give the AKP government the benefit of the doubt.

Still another reason why the transformations in question may take place would be the way the AKP government conducts itself. That government has not only been successful in the management of the economy and the conduct of foreign policy, and has avoided cheap populism; it has also been quite skillful in its approach towards the military. The government has acted in a courteous manner towards the military while it has gradually and carefully let the military know who was the boss. They could do this because they were able to give the military the impression that they took their responsibilities seriously and worked hard in order to successfully grapple with the problems the country has faced. In the process, they too must have contributed to the flourishing of a new military ethic that stressed subordination to the civilian authority under all kinds of circumstances.

These optimistic notes are based on the assumption that Erdoğan and those close to him in the higher echelons of the AKP do not have the "ulterior motives" that, as noted, the bulk of the intelligentsia attribute to them, and thus they are not, for instance, enthusiastic about Turkey becoming a full member of the EU for the primary purpose of clipping the wings of the military. The assumption in question seems to be plausible for several reasons. First, Erdoğan is a sincere Sufi, not interested in using religion for political purposes. Secondly, he is a conservative-democrat, with 
genuine responsiveness towards, and interest in, the welfare of the people. No doubt, he knows well that, with the accession of Turkey to the EU as full member, the economy will improve substantially and that will be in the best interest of the people. Thirdly, in Turkey, not only the military but also the bulk of the intelligentsia, civil societal organizations and the people at large would constitute an insurmountable barrier to any attempt at bringing back a state based on Islam, and one cannot assume that Erdoğan is unaware of this.

\section{Notes}

1. Kenneth W. Kemp and Charles Hudlin, "Civil Supremacy over the Military: Its Nature and Limits," Armed Forces and Society, Vol.19, No.1 (1992), p.22.

2. Tanel Demirel, "Civil-Military Relations in Turkey: Two Patterns of Civilian Behavior Towards the Military," Turkish Studies, Vol.4, No.3 (Autumn 2003), pp.1-25.

3. Nilüfer Narlı, "Civil-Military Relations in Turkey," Turkish Studies, Vol.1, No.1 (Spring 2000), pp.107-27.

4. Feride Acar, "Turgut Özal: Pious Agent of Liberal Transformation," in Metin Heper and Sabri Sayarı (eds.), Political Leaders and Democracy in Turkey (New York and Oxford: Lexington Books, 2002); and Ahmet Evin, "Demilitarization and Civilianization of the Regime," in Metin Heper and Ahmet Evin (eds.), Politics in the Third Turkish Republic (San Francisco and Oxford: Westview Press, 1994).

5. The late Dankwart A. Rustow talked about three major transformations that took place in republican Turkey, namely the cultural revolution of Atatürk, the democratic revolution of İsmet İnönü, and the economic revolution of Turgut Özal. See his “Turkey’s Liberal Revolution,” Middle East Review, Vol.12 (1985), pp.1-11.

6. Özal was also not very careful with formal procedures; he, for instance, inspected troops at resort places in shorts!

7. Metin Heper, "Demokrasimizin Sorunları" [The Problems of our Democracy], Doğu Batı, Vol.6, No.21 (2002-03), pp.159-68; and Metin Heper, "Seçim Sonuçlarının Değerlendirilmeleri ile İlgili Bazı Düşünceler" [Some Notes on the Analyses of Election Results], Türkiye Günlü̆̆̈̈, No.70 (2002), pp.23-7. On Bahçeli, the author also draws upon Metin Heper and Başak Ince, "Devlet Bahçeli and 'Far Right' Politics in Turkey, 1999-2002," unpublished paper.

8. In both the military and the AKP, the pattern of rule resembles democratic centralism: when an important decision is to be made there takes place an extensive exchange of opinion; then, the leader makes a decision and virtually everybody willingly complies with it.

9. George Harris, "The Role of the Military in Turkey: Guardians or Decision-Makers?" in Metin Heper and Ahmet Evin (eds.), State, Democracy and the Military: Turkey in the 1980s (Berlin and New York: Walter de Gruyter, 1988); Metin Heper and Aylin Güney, "The Military and the Consolidation of Democracy: The Recent Turkish Experience," Armed Forces and Society, Vol.26, No.4 (Summer 2000), pp.635-57.

10. Sedat Ergin, "Manşet Vermeyen İlk Genelkurmay Başkanı," [The First Chief of Staff Who Does Not Like to See his Name on the Headlines], Hürriyet (Istanbul daily), November 3, 2002.

11. Hürriyet, May 20, 2003.

12. Metin Heper, "The European Union, and the Military and Democracy in Turkey," South European Society and Politics, forthcoming.

13. Hürriyet, November 3, 2002.

14. Reported by journalist Yalçın Doğan in Hürriyet, August 23, 2003.

15. Hürriyet, July 9, 2004.

16. Milliyet (Istanbul daily), August 29, 2004.

17. Hürriyet, January 9, 2003. It should also be noted here that Özkök fasts during Ramadan. He once broke his fast during a MGK meeting along with the AKP members of that Council. 
18. Milliyet, October 4, 2004.

19. The Council of State is the highest administrative tribunal in Turkey.

20. The reform packages in question divested the MKG of its executive power, and rendered it a purely advisory body. For an elaboration, see Margriet Drent, "EU Conditionality Concerning Turkish Civil-Military Relations," prepared for the second meeting of the Task Force formed for the project, "Governance and the Military: Perspectives for Change in Turkey," Groningen, the Netherlands, July $13-14,2004$. More on this point below.

21. Hürriyet, November 6, 2003.

22. Milliyet, January 10, 2003.

23. Sabah (Istanbul daily), November 16, 2002.

24. January 19,2003 . February 28 was the day when the military-led pressure had begun for the eventual resignation of the coalition government led by Necmettin Erbakan of the religiously oriented Welfare Party (June 1997).

25. More on this controversy below.

26. Ergun Özbudun and Serap Yazıc1, Democratization Reforms in Turkey, 1993-2004 (Istanbul: TESEV Publications, 2004), pp.37-41.

27. On the characteristics of Sufism mentioned here, see Mark J. Sedgwick, Sufism: Essentials (Cairo: American University in Cairo Press, 2000). On Erdoğan as a Sufi, see Metin Heper and Şule Toktaş, "Islam, Modernity, and Democracy in Contemporary Turkey: The Case of Recep Tayyip Erdoğan," Muslim World, Vol.93, No.2 (April 2003), pp.157-85.

28. Metin Heper, "Conservative-Democratic Government by Pious People: The Justice and Development Party in Turkey," in Ibrahim M. Abu-Rabi (ed.), Blackwell Companion to Contemporary Islamic Thought (New York: Blackwell, forthcoming).

29. Radikal (Istanbul daily), March 22, 2004.

30. Sabah, May 19, 2004.

31. Zaman (Istanbul daily), February 13, 2004.

32. Milliyet, March 9, 2004.

33. Hürriyet, December 9, 2002. Although Turkey obtained a date from the EU for the start of accession negotiations, this will be an important matter of contention between the EU and Turkey in the ensuing negotiations.

34. Milliyet, April 21, 2004.

35. Hürriyet, Janaury 10, 2003. Gül's reservation was that it should be possible to appeal the decisions of the High Military Council at courts.

36. Milliyet, July 23, 2003.

37. Milliyet, September 8, 2003.

38. Sabah, May 3, 2003; Hürriyet, May 23, 2003.

39. Sabah, December 6, 2002. Is it plausible to argue, as Erdoğan did, that the military's relatively accommodating attitude towards the AKP might be due to the AKP's strong electoral support and the wide popular backing enjoyed by its leader? One may respond to this query by noting that the military has a basic respect for the constitutional order, with Özkök now arguing that the military should have more trust in the judgment of the people. It is also possible to suggest that the military's accommodating attitude in question may be attributed to their perception of the "good works" on the part of the government rather than to the electoral support. For (1) officers still become troubled if they come to the conclusion that a government is "not paying adequate attention to critical problems the country faces" and, on those occasions, they do not take into account that the government in question has the people's mandate; and (2) the opinions polls in Turkey continue to indicate that in the eyes of the people the military has a higher prestige than politicians.

40. Milliyet, July 5, 2003.

41. Hürriyet, January 9, 2003.

42. Milliyet, April 29, 2003.

43. Hürriyet, May 27, 2003.

44. Milliyet, May 20, 2003. 
45. Hürriyet, August 3, 2003. Since prime ministers head the meetings of the YAŞ, Erdoğan might have made these suggestions so that he would not have to sign the decisions about the dismissal of military officers on the grounds that they had been involved in political Islam.

46. Milliyet, May 2, 2003.

47. Hürriyet, May 2, 2004.

48. Ibid.

49. Sabah, May 5, 2004.

50. Hürriyet, May 7, 2004. 